\title{
Cerebral cortex perfusion rates in dementia
}

\author{
M. D. O'BRIEN ${ }^{1}$ AND B. L. MALLETT \\ From the Department of Medicine, Guy's Hospital Medical School, London, and Fairfield \\ Hospital, Hitchin, Herts.
}

SUMMARY Cerebral cortex perfusion rates (CPR) were measured in 11 patients with dementia. In six patients the dementia appeared to be due to a primary neuronal degeneration and in the remainder it appeared to be secondary to vascular disease. In the context of blood flow measurement, it is suggested that the terms primary and secondary dementia are preferable to the terms presenile and senile dementia, because the latter are classified by age alone and the terms have no aetiological or pathological significance. The perfusion rates in patients with primary dementia were within normal limits for their age, whereas those in patients with secondary dementia were significantly reduced. This difference is likely to apply only if the measurements are made early in the course of the disease.

Reduction in both total and regional cerebral blood flow has been reported in dementia (Kety, 1956; Lassen, Feinberg, and Lane, 1960; Sokoloff, 1966). The present study was planned to compare the cerebral cortex perfusion rates (CPR) in patients whose dementia was due to primary neuronal degeneration and those in whom the dementia appeared to be secondary to vascular disease; and further to see if there was a correlation between CPR and the appearances on pneumoencephalography.

\section{PATIENTS AND METHODS}

Cerebral cortex perfusion rates were measured in 11 patients admitted to Guy's Hospital, London, for investigation of dementia; patients with tumours were not included in the series and all patients were in the early stages of the disease. Detailed case histories and investigations were assessed independently by both of us and patients allocated to the primary or secondary group using the following criteria:

The primary group includes hereditary or congenitally determined disease, such as Huntington's chorea (patients nos. 2, 5, and 12); cortical neuronal degeneration associated with degenerative neurological disease elsewhere, as in motor neurone disease (patient no. 10) (van Bogaert, 1925). This group also includes patients with no other disease of the nervous system, or elsewhere, and in particular no evidence of vascular disease. For the

'Present address and reprint requests: Regional Neurological Centre, Newcastle General Hospital, Newcastle upon Tyne, NE4 6BE, purpose of this study toxic or deficiency dementias-for example, vitamin $B_{12}$ deficiency-would be included in the primary group.

The criteria for inclusion of a patient in the secondary group were evidence of cerebral vascular disease, in the history, on clinical examination, or by arteriography. It also includes patients with evidence of systemic vascular disease, such as hypertension, absent peripheral pulses, and the presence of arterial bruits.

A further two patients were studied. One of these was a lady of 65 years (patient no. 11) with polycythaemia rubra vera. When first seen she was hypertensive (BP $200 / 110 \mathrm{~mm} \mathrm{Hg}$ ) and demented, with a mild spastic quadriparesis but no other focal neurological signs. Investigations showed her haemoglobin to be $21.2 \mathrm{~g} /$ $100 \mathrm{ml}$., PCV $65 \%$, MCHC 32\%, ESR $1 \mathrm{~mm} /$ one hour, WBC $10,000 /$ c. mm, platelets $375,000 / \mathrm{c}$. mm, blood urea $61 \mathrm{mg} / 100 \mathrm{ml}$., uric acid $8.6 \mathrm{mg} / 100 \mathrm{ml}$. She was studied again 28 days later when her haemoglobin had been reduced to $13.6 \mathrm{~g} / 100 \mathrm{ml}$., PCV to $43 \%$, MCHC $31 \%$, platelets $344,000 / \mathrm{c}$. mm, and BP $140 / 100 \mathrm{~mm} \mathrm{Hg}$. However she was more confused and had developed a right VI nerve palsy, a left VII nerve palsy, and her spastic quadriparesis was more severe.

The other patient was a girl of 21 who had suffered a right hemiplegia at the age of 2 , which had persisted and she later developed epilepsy. The aetiology of the hemiplegia was thought to be vascular, since it occurred suddenly during an attack of gastroenteritis when she was severely dehydrated. Pneumoencephalography and left carotid arteriography were normal.

Fronto-parietal CPRs were measured in each patient using the ${ }^{133}$ Xenon inhalation technique, which gives simultaneous bilateral measurements (Mallett and Veall 1965; Veall and Mallett, 1966). The forty-minute 
${ }^{133}$ Xenon desaturation curve was subjected to a deconvolution procedure with the end-expired air curve into three exponential components using an analogue computer (Crawley, 1968; Abrams, Crawley, Green, and Veall, 1969). The cerebral cortex perfusion rates were calculated from the half-life of the fast component using a tissue/blood partition coefficient for ${ }^{133}$ Xenon appropriate to the haematocrit (Veall and Mallett, 1965). The result was expressed as $\mathrm{ml}$. blood $/ 100 \mathrm{~g}$ cortex/min. The $\mathrm{pCO}_{2}$ was estimated before and after each measurement by the rebreathing technique (Campbell and Howell, 1960). After each procedure, which was carried out in the sitting position, the patient's blood pressure was recorded with a sphygomomanometer. In every case the measurements were done before any contrast radiology was undertaken; all patients subsequently had pneumoencephalography and a number underwent angiography.

\section{RESULTS}

The results found in the 'primary group' are shown in Table 1, those in the 'secondary group' in Table 2, and the other two patients in Table 3.

The mean CPR in the primary group $(45.3 \mathrm{ml} . / \mathrm{g} /$ min) is significantly lower than that of a series of normal persons (mean ( \pm SEM) of both hemispheres in 39 normal subjects aged over 20 is $54.7( \pm 2.4$ $\mathrm{ml} / \mathrm{g} / \mathrm{min}$ ), but there is no difference when the primary group is compared with an older group of normal subjects (mean $( \pm$ SEM) of bilateral measurements in 11 normal subjects over the age of 40 is $44.3 \mathrm{ml} . / \mathrm{g} / \mathrm{min}$ ).

In the group of patients with dementia secondary

TABLE 1

PRIMARY NEURONAL DEGENERATIONS

\begin{tabular}{|c|c|c|c|c|c|c|}
\hline $\begin{array}{l}\text { Patient } \\
\text { no. }\end{array}$ & $\begin{array}{l}\text { Age } \\
\text { (yr) }\end{array}$ & Sex & $\begin{array}{l}\text { Blood pressure } \\
\quad(\mathrm{mm} \mathrm{Hg})\end{array}$ & $\begin{array}{l}\text { Mean arterial blood pressure } \\
\qquad(\mathrm{mm} \mathrm{Hg})\end{array}$ & $\begin{array}{l}\text { Cortex perfusion rate } \\
\text { (ml./100 g cortex/min) }\end{array}$ & $\begin{array}{c}\text { Cerebrovascular } \\
\text { resistance } \\
(M A B P / C P R)\end{array}$ \\
\hline $\begin{array}{r}1 \\
2 \\
5 \\
6 \\
10 \\
12\end{array}$ & $\begin{array}{l}69 \\
57 \\
55 \\
65 \\
59 \\
49\end{array}$ & $\begin{array}{l}\mathbf{F} \\
\mathbf{F} \\
\mathbf{F} \\
\mathbf{F} \\
\mathbf{M} \\
\mathbf{M}\end{array}$ & $\begin{array}{l}160 / 80 \\
150 / 90 \\
150 / 90 \\
180 / 75 \\
140 / 90 \\
140 / 90\end{array}$ & $\begin{array}{l}107 \\
110 \\
110 \\
110 \\
107 \\
100\end{array}$ & $\begin{array}{l}38 \cdot 2 \\
51 \cdot 0 \\
51 \cdot 8 \\
49 \cdot 0 \\
40 \cdot 9 \\
40 \cdot 7\end{array}$ & $\begin{array}{l}2 \cdot 8 \\
2 \cdot 2 \\
2 \cdot 1 \\
2 \cdot 2 \\
2 \cdot 6 \\
2 \cdot 5\end{array}$ \\
\hline & 59 & & & 107 & $45 \cdot 3$ & 2.4 \\
\hline
\end{tabular}

TABLE 2

'SECONDARY' DEMENTIA ?

\begin{tabular}{|c|c|c|c|c|c|c|}
\hline $\begin{array}{l}\text { Patient } \\
\text { no. }\end{array}$ & $\begin{array}{l}\text { Age } \\
(y r)\end{array}$ & Sex & $\begin{array}{l}\text { Blood pressure } \\
\quad(\mathrm{mm} \mathrm{Hg})\end{array}$ & $\begin{array}{l}\text { Mean arterial blood pressure } \\
(\mathrm{mm} H \mathrm{Hg})\end{array}$ & $\begin{array}{l}\text { Cortex perfusion rate } \\
(\mathrm{ml} / 100 \mathrm{~g} \text { cortex } / \mathrm{min})\end{array}$ & $\begin{array}{c}\text { Cerebrovascular } \\
\text { resistance } \\
(M A B P / C P R)\end{array}$ \\
\hline $\begin{array}{r}3 \\
7 \\
8 \\
9 \\
13\end{array}$ & $\begin{array}{l}58 \\
61 \\
73 \\
68 \\
59\end{array}$ & $\begin{array}{l}\mathbf{M} \\
\mathbf{M} \\
\mathbf{M} \\
\mathbf{F} \\
\mathbf{M}\end{array}$ & $\begin{array}{l}190 / 115 \\
160 / 105 \\
120 / 95 \\
170 / 100 \\
120 / 80\end{array}$ & $\begin{array}{r}140 \\
123 \\
103 \\
123 \\
93\end{array}$ & $\begin{array}{l}28 \cdot 3 \\
42 \cdot 8 \\
28 \cdot 7 \\
37 \cdot 6 \\
37 \cdot 0\end{array}$ & $\begin{array}{l}4 \cdot 9 \\
2.9 \\
3 \cdot 6 \\
3 \cdot 3 \\
2 \cdot 5\end{array}$ \\
\hline & 64 & & & 116 & 34.9 & 3.4 \\
\hline
\end{tabular}

TABLE 3

FURTHER TWO PATIENTS STUDIED

\begin{tabular}{|c|c|c|c|c|c|c|c|c|}
\hline \multirow[t]{2}{*}{$\begin{array}{l}\text { Patient } \\
\text { no. }\end{array}$} & \multirow[t]{2}{*}{$\begin{array}{l}\text { Age } \\
\text { (yr) }\end{array}$} & \multirow[t]{2}{*}{ Sex } & \multirow[t]{2}{*}{$\begin{array}{l}\text { Blood pressure } \\
\quad(\mathrm{mm} \mathrm{Hg})\end{array}$} & \multirow[t]{2}{*}{$\begin{array}{c}\text { Mean arterial blood pressure } \\
(\mathrm{mm} \mathrm{Hg})\end{array}$} & \multicolumn{2}{|c|}{$\begin{array}{l}\text { Cortex perfusion rate } \\
(\mathrm{ml} / 100 \mathrm{~g} \text { cortex } / \mathrm{min})\end{array}$} & \multicolumn{2}{|c|}{$\begin{array}{c}\text { Cerebrovascular } \\
\text { resistance } \\
(M A B P / C P R)\end{array}$} \\
\hline & & & & & $\boldsymbol{L}$ & $\boldsymbol{R}$ & $\boldsymbol{L}$ & $\boldsymbol{R}$ \\
\hline 4 & 21 & $\mathbf{F}$ & $120 / 80$ & 93 & $36 \cdot 0$ & $43 \cdot 2$ & $2 \cdot 6$ & $2 \cdot 2$ \\
\hline 11 & 65 & $\mathbf{F}$ & $\begin{array}{l}200 / 110 \\
140 / 100\end{array}$ & $\begin{array}{l}140 \\
113\end{array}$ & \multicolumn{2}{|c|}{$\begin{array}{l}32 \cdot 7 \\
28 \cdot 8\end{array}$} & \multicolumn{2}{|c|}{$\begin{array}{l}4 \cdot 28 \\
3 \cdot 9\end{array}$} \\
\hline
\end{tabular}


to vascular disease, including the second measurement on patient no. 11 , the mean CPR $(33.9 \mathrm{ml} . / \mathrm{g} /$ $\mathrm{min}$ ) is significantly lower than the values obtained both in patients with primary dementia $(0.01>$ $P>0.005)$ and in normal persons $(0.01>P>$ 0.005 ). There is also a difference in the mean arterial blood pressures of the two groups of patients but this is not statistically significant at the $5 \%$ level, though it contributes to the significant difference in cerebrovascular resistance (CVR) $(0.01>\mathrm{P}>$ 0.005). In all patients $\mathrm{pCO}_{2}$ values were within one standard deviation of their mean. The cerebral cortex perfusion rate in the patient with polycythaemia rubra vera was extremely low and the CVR was very high, as would be expected in this condition.

After treatment there was a considerable fall in her CVR, but despite this there was a further slight fall in CPR.

Patient no. 4 shows that CPR measurement may reflect the functional state of a hemisphere more accurately than angiography or pneumoencephalography, since both these neuroradiological investigations were within normal limits, whereas the blood flow measurements show a clear disparity between the two hemispheres.

\section{DISCUSSION}

Dementia is a term used to describe a clinical syndrome due to organic disease of the brain and carries no specific pathological implications. The cause in each case must be investigated because it is sometimes remediable. If no specific cause can be found, dementia is sometimes classified by reference to an arbitrarily chosen age into 'presenile' or 'senile'. It is doubtful whether this classification serves a useful purpose because it takes no account of pathology or aetiology; a classification which does take some note of the nature of the condition is to be preferred. The use of the word senile in this context is also undesirable because old age by itself is not necessarily associated with dementia.

When the present study was planned, it was postulated that the cerebral blood flow of patients with a primary neuronal degeneration might differ from that of patients whose dementia was secondary to vascular disease (O'Brien, 1969). In the first case the loss of nerve cells is due to some cellular abnormality while the blood supply remains intact, so that the flow per unit mass (perfusion rate) might remain constant and a ${ }^{133}$ Xenon clearance curve would have a normal slope, although the intercept on the ordinate would fall in parallel with the loss of cortical tissue bulk. However, cerebral blood flow is finely adjusted to the metabolic demand and, since the degenerative process primarily affects the metabolically more active cells, which are replaced (per unit mass of tissue) by less metabolically active cells, some reduction in flow proportional to this reduced metabolic demand would occur.

In dementia secondary to vascular disease, healthy neurones are imperilled by inadequate blood supply. In these circumstances there might first be an increase in the arteriovenous oxygen and glucose differences and this phenomenon has been observed (Scheinberg, 1950; Heyman, Patterson, Duke, and Battey, 1953; Kety, 1956; Sokoloff, 1966; Geraud, Bes, Delpha, and Marc-Vergnes, 1969) cell death occurring when this compensatory mechanism fails. The cerebral cortex perfusion rate is likely to be reduced early in the course of the disease and the reduction would be out of proportion to the degree of dementia. This differentiation would probably apply only in the early stages of the disease: longstanding cases of either type are likely to show both a reduced flow and a reduced cell mass. All the patients studied in this series were investigated soon after the earliest manifestations of a dementing process were recognized and this may account for differences between this series and investigations carried out on patients with dementia of long standing.

A major difficulty lies in the clinical differentiation of primary and secondary dementias. There may be objections to this classification on pathological grounds, but it is probably adequate for the purposes of interpreting blood flow data. Clearly the secondary group may include patients in whom primary neuronal degeneration co-exists with vascular disease. However, Tomlinson, Blessed, and Roth (1970) have reported a series of 50 consecutive patients with dementia (mean age 76 years) examined at necropsy and compared them with a group of 50 normal patients matched for age; $50 \%$ were found to have Alzheimer's disease alone, $18 \%$ to have vascular disease lone, $20 \%$ had changes which were not significantly different from normals matched for age, and only $8 \%$ had both vascular disease and Alzheimer's disease. On this basis the 'secondary group' (average age 64) is unlikely to be sufficiently contaminated to alter the significance of the results.

An attempt was made to correlate the degree of ventricular enlargement and the degree of cortical atrophy with the blood flow. These estimates were made from the pneumoencephalographic appearances and graded according to an arbitrary scale. It was thought that the observation that some patients showed marked ventricular dilatation with relative preservation of the cortex, while others showed the reverse picture, might have a vascular basis; no other pathological or aetiological explana- 
tion has been substantiated. However, no correlation existed between the blood flow and the size of the ventricles or the degree of cortical atrophy; it may be that the explanation for this phenomenon lies in some abnormality of the CSF dynamics.

The results show the importance of comparing regional cerebral cortex perfusion rates in elderly patients with a group of normal subjects matched for age; unfortunately, this is not practicable with most methods of measuring cerebral blood flow currently available. Sokoloff (1966) has shown that there is no significant change in cerebral blood flow with age alone; this conclusion was based on results in a group of very highly selected subjects who were extensively investigated before admission to the series. Elderly asymptomatic subjects do show a fall in cerebral blood flow with age (Kety, 1956; Gottstein, 1969) which is probably due to subclinical vascular disease (Sokoloff, 1966). These studies were all estimates of mean perfusion rates for the whole brain and not of cortex perfusion rates; it is the cortex which is most affected by the ageing process and this is less likely to be reflected in total blood flow measurements. These results are, therefore, an underestimation of the reduction in CPR in asymptomatic elderly subjects. There is some degree of vascular degeneration in all people of middle age and older and there is also a progressive fall-out of neurones from an early age. It is therefore to be expected that there would be a small but progressive fall in CPR with age in parallel with the loss of the faster perfused elements, and in addition a variable loss due to degenerative vascular disease. The cerebral cortex perfusion rate in a group drawn from a population of clinically normal subjects of middle age and above is therefore likely to be slower and to show a greater variance than a younger age group. Analysis of the variance by the F test of CPR in the two age groups of normal subjects previously quoted does not show a significant difference at the $5 \%$ level, but the numbers of older clinically normal subjects is small and does not include any subjects over 60 . However, measurements of total cerebral blood flow support this hypothesis; Lassen et al. (1960) reported a series of 11 normal young subjects (mean age 24.2) with a mean whole brain perfusion rate of $42.95 \pm 3.69 \mathrm{ml} . / \mathrm{g} / \mathrm{min}$ and a series of five subjects with a mean age of 72 and blood flow of $42.74 \pm$ $11.24 \mathrm{ml} / \mathrm{g} / \mathrm{min}$. The $\mathrm{F}$ test on this data shows a highly significant difference $(P<0.01)$ in variances.

In patients with a primary neuronal degeneration, the CPR falls in relation to the loss of tissue bulk and metabolic demand; but in those patients whose dementia is secondary to vascular disease the CPR is reduced early in the course of the disease and this is out of proportion to the degree of cortical atrophy.
We are grateful to Dr. M. J. McArdle, Dr. I. Mackenzie, Dr. R. Heirons, and Professor W. J. R. Butterfield for permission to study their patients; to Mr. N. Veall for his constant help and advice, to Mr. J. Crawley who carried out the computer analysis of the results, to Dr. R.D. Hoare for the neuroradiological investigations, and to Mr. J. Green for technical assistance.

\section{REFERENCES}

Abrams, M. E., Crawley, J. C. W., Green, J. R., and Veall, N. (1969). A comparative study of digital and analogue computer techniques for deconvolution procedures in clinical tracer studies. Phys. in Med. Biol., 14, 225-232.

Campbell, E. J. M., and Howell, J. B. L. (1960). Simple rapid methods of estimating arterial and mixed venous $\mathrm{pCO}_{2}$. Brit. med. J., 1, 458-462.

Crawley, J. C. W. (1968). An analogue computer for calculating blood perfusion rates. Bio-med. Engng, 3, 256-261.

van Bogaert, L. (1925). Les troubles mentaux dans la sclérose latérale amyotrophique. Encephale, 20, 27-47.

Geraud, J., Bes, A., Delpha, M., and Marc-Vergnes, J. P. (1969). In Research on the Cerebral Circulation, Chapter 18. Edited by J. S. Meyer, H. Lechner, and O. Eichhorn. Thomas: Illinois.

Gottstein, U. (1969). The effect of drugs on cerebral blood flow especially in patients of older age. Pharmakopsychiat. Neuro-psychopharmakol., 2, 100-109.

Heyman, A., Patterson, J. L., Jnr., Duke, T. W., and Battey, L. L. (1953). The cerebral circulation and metabolism in arteriosclerotic and hypertensive cerebrovascular disease. With observations on the effects of inhalation on different concentrations of oxygen. New Engl. J. Med., 249, 223-229.

Kety, S. S. (1956). Human cerebral blood flow and oxygen consumption as related to ageing. Ass. Res. nerv. Dis. Proc., 35, 31-45.

Lassen, N. A., Feinberg, I., and Lane, M. H. (1960). Bilateral studies of cerebral oxygen uptake in the young and aged normal subjects and in patients with organic dementia. J. clin. Invest., 39, 491-500.

Mallett, B. L., and Veall, N. (1965). The measurement of regional cerebral clearance rates in man using xenon133 inhalation and extracranial recording. Clin. Sci., 29, 179-191.

O'Brien, M. D. (1969). In Research on the Cerebral Circulation, p. 218. Edited by J. S. Meyer, H. Lechner, and O. Eichhorn. Thomas: Illinois.

Scheinberg, P. (1950). Cerebral blood flow in vascular disease of the brain. With observations on the effects of stellate ganglion block. Amer.J. Med., 8, 139-147.

Sokoloff, L. (1966). Cerebral circulatory and metabolic changes associated with ageing. Ass. Res. nerv. Dis. Proc., 41, 237-254.

Tomlinson, B. E., Blessed, G., and Roth, M. (1970). Observation on the brains of demented old people. J. neurol. Sci. (in press).

Veall, N., and Mallett, B. L. (1965). The partition of trace amounts of Xenon between human blood and brain tissues at $37^{\circ} \mathrm{C}$. Phys. in Med. Biol., 10, 375-380.

Veall, N., and Mallett, B. L. (1966). Regional cerebral blood flow determination by ${ }^{133} \mathrm{Xe}$ inhalation and external recording: the effect of arterial recirculation. Clin. Sci., 30, 353-369. 